\title{
Does Corporate Governance Matter? Evidence from Accounting Conservatism Practices among Jordanian Listed Companies
}

\author{
Dea'a Al-Deen Omar Al-Sraheen, Faudziah Hanim Fadzil, Syed Soffian Bin Syed Ismail \\ Othman Yeop Abdullah Graduate School of Business and School of Accountancy \\ Northern University of Malaysia, Malaysia \\ Corresponding Email: deaa_sraheen@yahoo.com
}

DOI:10.5296/ ijld.v4i3.6507 URL: http://dx.doi.org/10.5296/ ijld.v4i3.6507

\begin{abstract}
The problem in accounting conservatism practice has been the focus of everyone. In our view, it was attributed amongst other factors to the weak of corporate governance practices. Such study develops an empirical model on the association between some mechanisms of corporate governance and accounting conservatism in terms of foreign ownership, board independence, board size and audit committee, through choosing Jordanian listed companies as research sample. The data were collected through using the annual reports of 113 Jordanian companies for year 2011. Four hypotheses were developed in this study. Upon using the multiple regression analysis, three of them were significant while one was not. This study concludes that there is a positive and significant association between each of foreign ownership, board independence and audit committee and accounting conservatism. While a negative and insignificant relationship between board size and conservatism. In addition, this study opens up opportunities and provides avenues for more in-depth research related to the accounting conservatism.
\end{abstract}

Keywords: Accounting conservatism, corporate governance, accrual-based, Jordan

\footnotetext{
${ }^{1}$ Correspondence: Dea'a Al-Deen Omar Al-Sraheen, School of Accountancy, College of Business, Northern University of Malaysia, 06010 UUM Sintok. E-mail: Deaa_Sraheen@yahoo.com
} 


\section{Introduction}

Accounting conservatism is deemed as the most effective principle underpinning accounting valuation and has a lengthy historical application to financial accounting exceeding, five centuries (Basu, 1997; Sterling, 1970). Nonetheless, the concept of conservatism faces significant criticism by academics, capital market regulators and standards-setters. Critics such as La Fond and Watts (2008) argued that conservatism leads to understate of net assets in the present period leading to overstate of earnings in the future periods due to the understate of future expenses. Despite heavy criticism, previous empirical studies reported that conservatism has increased during the past decades (Givoly and Hayn, 2002; Lobo \& Zhou, 2006). This suggests, critics may overlook major benefits of conservatism. The lengthy persistence and resilience to criticism of accounting conservatism are intriguing empirical impasses producing a number of significant unanswered questions.

Previous studies have defined conservatism by the aphorism "anticipate no profit, but anticipates all losses" (Watts, 2003a). Basu (1997) has defined accounting conservatism as earnings asymmetric timeliness that requires high level of verification for recognizing of good news as an economic profit than recognizing bad news as an economic loss. Givoly and Hayn (2000) have defined accounting conservatism as a choice between the principles of accounting that lead to decrease the cumulative earnings by slower recognition of revenue. All previous definitions have acknowledged that earnings that reported under accounting conservatism practices are understated rather than overstated.

Conservatism practices contribute to accounting field through many facets. Agency theory is the field that received much attention in this aspect, where previous studies have documented that conservatism decreases agency conflict as it limits over payment of incentive to directors (Kwon, Newman \&Suh, 2001), permitted for early detection of adverse net present value projects as it promptly recognizes expected losses (Ball, 2001). Additionally, prior studies suggested that conservatism limits the opportunistic behavior of managers (Brown, He \&Teitel, 2006; Chen, Hemmer \& Zhang, 2007; Watts, 2003a) and decreases information asymmetry among outside shareholders and managers (LaFond\& Watts, 2008). Moreover, conservatism is more beneficial in monitoring the cost of suboptimal managerial decisions than if the earnings were measured liberally or neutrally (Kwon, 2005). The usefulness of conservatism in the agency relationship, ultimately enhance the usefulness of financial reports (Ball \& Shivakumar, 2006) and improve firm value (Watts, 2003b).

Kung, James and Cheng (2008) reported that conservatism is a significant underlying attribute of reporting quality. Ball and Shivakumar (2005) meanwhile have reported that conservatism is a significant attribute of earnings quality because it makes financial reports more useful and informative. Therefore, stakeholders are better capacity to monitor performance of firm. In addition, Ball, Robin and $\mathrm{Wu}$ (2003) believed that conservative accounting practices present more timely information giving creditors and shareholders' better opportunities to make main decisions on loss making projects. 


\section{Theoretical Background}

Interests' conflicts among corporate directors and other parties to the firms arise due to that the corporate managers control effectively corporate assets while they do not have a significant amount of equity in their companies (Ahmed \& Duellman, 2007; Jensen \& Meckling, 1976). Some of previous studies have suggested that it's difficult to control and resolve such conflicts through contracts, because it is very costly, if not impossible, to create and impose full contracts (e.g. Fama \& Jensen, 1983; Hart, 1995).Therefore, under a world with not complete contracts; the mechanisms of corporate governance have emerged to limit such conflicts. These governance mechanisms differ in terms of their costs and benefits, due to differences with corporate attributes such as the size, leverage, of investment opportunity (Ahmed \& Duellman, 2007; Watts, 2006). Based on this disparity also, the task of providing an optimal combination of mechanisms of corporate governance is not easy. Consequently, the current paper focuses on the relationship between foreign ownership, board independence, board size and audit committee.

In addition, previous studies have documented that accounting conservatism contributes an important role in limiting agency conflict (Kwon, Newman \&Suh, 2001). As well, conservatism practices can also control the problems of moral hazard arising from agency conflict such as aggressive earnings management (Dea'a, 2014).

\section{Research Hypotheses}

\subsection{The relationship between foreign ownership and accounting conservatism}

Previous studies showed that foreign investors in capital markets give prioritize for equity shares of companies with low level of asymmetry information to those with high level (Ball \& Shivakumar, 2005; LaFond\& Watts, 2008). If foreigner investors were attracted to the firms that have rich information and have a low level of asymmetry, the size of foreign shareholdings should be negatively associated to the level of asymmetry (Anonymous, 1996; Fan \& Wong, 2002). LaFond and Watts (2008) showed evidence that there is positive relationship between asymmetry of information among outside and inside investors and the level of conservatism and thus the information asymmetry drives to conservatism. They also showed that conservatism decreases the managers' incentives and their ability to manage and manipulate financial figures. In the bottom line, the issues that generate because of the asymmetry of information between managers shareholders require more employ of financial statements in contracting and communicating, and thus polarization more demand for conservative practices (Ball \& Shivakumar, 2005).

Since the financial crisis in Asia in 1997, the weak transparency level in the capital markets of most Asian countries has received great interest from the of global investment society side. It has been reported that the financial disclosures of companies are not transparent sufficiently to assist foreign investors evaluate the timing and amount of expected flow of cash in future (e.g. Ang \& Ma, 1999; Ball, Kothari, \& Robin, 2000). This insufficient level of transparency leads to increase the level of asymmetric information in such markets, which leads also to increase the capital cost from external suppliers' side. 
In this regard, Jordanian government has issued and revised a set of important laws and regulations to increase the level of transparency which helps foreign investors to allocate their investments and expected the future cash flows and thus more confidence of financial reports. These regulations and laws such as Privatization Law No. 25 of the year (2000), Banks Law in (2000) and Corporate Governance Code (2009) have been issued in order to encourage and attract the investment by non-Jordanians and to insure a high level of earning quality through adopting a higher level of conservatism (Faudziah, Dea'a \& Ismail, 2014; Hamdan, 2011; Hamdan, 2012a; Zureigat, 2011). Therefore, this paper employs foreign ownership to show an important aspect of Jordanian ownership structure that interprets the Jordanian business environment. In conclusion, agency theory reported that foreign ownership enhances quality of financial statements through conservatism practices. Therefore, the following hypothesis is suggested as follows:

\section{H1: There is a positive relationship between foreign ownership and accounting conservatism.}

\subsection{The relationship between board characteristics and accounting conservatism}

Board of directors plays a vital role in the governance of large institutions (Lanfranconi\& Robertson, 2002). Boards also help control and monitor the senior directors' behaviour, thereby protecting the shareholder's interests. Lara, Osma, and Penalva (2007) and Rodriguez (2010) suggested that the existence of independent directors on the corporate board help to ensures independence of corporate board from the management. In addition, independent directors can contribute to solving the disagreements between the internal managers or between the residual claimants and internal managers. Thus, boards comprising independent managers will give a counterbalance so that the insider managers do not take advantage of their position and sacrifice the wealth of shareholders. Pfeffer and Salancik (2003) showed that the existence of independent directors would enhance the flow of data, and hence protect the company resources and decrease uncertainty.

A growing related literature have documented that the transparency and information asymmetry of firms influence characteristics of its board structure in general, and the percentage of independence directorsin particular (Armstrong, Core \&Guay, 2014). Previous studies argued that independent directors find it difficult in monitoring and advising roles particularly when the processing costs, information transfer and asymmetry of information are high, and thus that companies with high level of asymmetry of information choose to have low level of independent directors (e.g., Linck, Netter \& Yang, 2008; Lehn, Patro \& Zhao, 2009). Previous studies such as Pfeffer (1972) and Ellstrand (1999) have used resource dependence theory to examine boards focus on board composition and its size as indicators of the ability of boards to provide important resources to the corporate. Pfeffer (1972) for instance, reported that board size relates to the corporate environmental needs and those with more correlation require a higher level of outside directors. Therefore, this study assumes:

H2: There is a positive relationship between board independence and accounting conservatism.

As for board size, there are mixed views about the role of board size in the literature. Agoraki, 
Delis and Staikouras (2010) concluded that larger size of boards is less effective than smaller size of boards due to difficulties in coordination of task. Lasfer (2004) reported also that the directors on a large board are less likely to criticize the policies of top management, hence are subject to the control of CEO. Further, large board tends to employ less meaningful discussion since too many directors attended in the discussion, making it need more time and effort to achieve cohesiveness. Further, a large board is less effective due to the slowdown in decision making, and one member will depend on other members to monitor management. As well, Hermalin and Weisbach (2003) Bhagat and Black (2000) showed that large boards are less involved in strategic decision-making.

On the other hand, Dalton and Dalton (2005) suggested that a large size of board provides a wider range of expertise and knowledge. This finding is partly supported by Akhtaruddin, Hossain and Yao (2009) through their results that found a positive relationship between size of board and voluntary disclosure. Based on this view, the current paper suggests the following hypothesis:

H3: There is a positive relationship between large board size and accounting conservatism.

\subsection{The relationship between Audit committee and accounting conservatism}

Audit committee is considered as the indicator to state whether the presence an audit committee adds more credibility to the financial data issued by a company (Abbott \& Parker, 2000; Bedard, Chtourou \& Courteau, 2004; Klein, 2002). Previous literatures have determined three regulatory responsibilities of audit committee (e.g., monitoring the external audit function, ensuring the impartiality of the financial reports and scrutinizing the process of internal audit), then the audit committee will be deemed as effective (DeZoort, Hermanson \& Archambeault, 2002; Vera-Munoz 2005).

Audit committee did not receive much attention by researchers and regulators, despite the important role of audit committees in various fields (Collier \& Gregory, 2000; Abdullatif, 2010). The collapse of the largest firm, Enron Corporation, in the U.S. history in 2001 urged superior firm accountability from investors and regulators alike. Consequently, the U.S. Congress established a new legislation known as the Sarbanes-Oxley Act that mandates all public companies to set up audit committees. The Act also stipulates the audit committees responsibilities and composition (Congress of the United States of America, 2002). Shortly after, other nations like Canada, the U.K. and Australia also acknowledged the audit committee's oversight responsibilities in similar terms as stipulated in SOX. The established regulatory bodies in the above countries are the LSE, the Toronto Stock Exchange, British Financial Reporting Council, Canadian Securities Administrators and the ASX.

In Jordan, the Corporate Governance Code for shareholding corporate listed under the ASE has identified the duties of the audit committee that holds the task of monitoring and overseeing accounting and auditing activities in the firm (ASE, 2009). Gay and Simnett (2007) have defined the audit committee as directors' committee responsible for liaising with the internal and external audit functions and overseeing external financial reporting. The audit 


\section{Macrothink}

International Journal of Learning \& Development

ISSN 2164-4063

2014, Vol. 4, No. 4

committee performs many of the main functions; while the main responsibility of the audit committee is to supervise and manage the process of financial reporting (Klein, 2002). In practice, Nimer, Warrad and Khuraisat (2012) found that the performance of the audit committees in Jordanian listed firms seem to be poor and ineffective due to the constraints on audit committees' members' work and also the weak independence of their members as their results have shown. They also showed that most of the audit committees' members have close relationships with the members of board of directors and the top management of the firms. As well, Abu-Haija (2012) found that the presence of audit committee negatively correlated with the manipulation in financial reports in Jordan, and he concluded that $51.7 \%$ of Jordanian listed firms don't have an audit committee.

This study employs audit committee because it's considered as a key institution in the context of corporate governance, as well helps the boards to fulfil their fiduciary and financial responsibilities to shareholders. Therefore, it can be hypothesized that:

H4: There is a positive relationship between the existence of audit committee and accounting conservatism.

\section{Sample and Data}

This study examines all industrial and services firms listed under ASE, for the year 2011. The total number of these firms in 2011 is 130 firms. 17 firms are excluded from the current study due to insufficient disclosure for the necessary data. Accordingly, remaining is 113 firms. In addition, all firms under the financial sector are also excluded because they are subjected to additional rules and requirements. For the analysis purposes, all secondary data are hand-collected from the annual reports of firms.

\section{Research model and variables measurement}

- Accounting Conservatism: this study uses the accrual-based measure as developed by (Givoly \& Hayn, 2000) to measure accounting conservatism. There has not been a detected in the literature on any possible a bias in this measure, as well as this measurement is more sophisticated than other measurements (Wang, 2009). The simple form is shown as follows:

$$
\text { Accruals }=\frac{\text { Income }+ \text { DepreciationExpenses }- \text { OperatingCashflows }}{\text { TotalAssets }}
$$

$$
\text { ACCR }=\frac{\text { Accruals }}{3 \text { years }} *(-1)
$$

- Foreign Ownership: is considered an additional dimension because of its importance in Jordanian environment as an emerging market. Based on the 
previous studies, foreign ownership was computed as the shares' percentage held by foreigners to total number of shares (Ali, Salleh\& Hassan, 2008; Klai \& Omri, 2011).

- Board Independence: was computed as the number of outside directors as a proportion of board size (Hayes, Mehran \& Schaefer, 2004; Klein, 1998).

- Board Size: measured using the total number of board members (Ahmed and Duellman, 2007).

- Audit Committee: was computed by the presence of audit committee in the firm, coded 1 if there is an audit committee in the firm and coded 0 otherwise (Goodwin \&Seow, 2002; Gulzar\& Wang, 2011).

Consequently, the current regression model employs to test the association between foreign ownership, board independence, board size and audit committee and accounting conservatism is as follows:

$A C C R_{i t}=\beta_{0}+\beta_{1} F O R E_{i t}+\beta_{2} B I N D_{i t}+\beta_{3} B S I Z_{i t}+\beta_{4} A C_{i t}+\varepsilon_{i t}$

\section{Where}

Table I: Variables Definition

\section{Symbols Variables Definition and Measurement}

ACCR Accrual-based measure of accounting conservatism $=[$ (income + depreciation expenses - operating cash flows) $] \div$ Total assets.

$\mathrm{ACCR}=($ Accruals $/ 3$ years $) X(-1)$.

FORE Foreign ownership: measured as the percentage of shares held by foreigners to total number of firm's shares.

BIND Board independence measured proportion of independent directors to total directors on board.

BSIZ Board size is the natural logarithm of total number of board members.

AC Audit Committee measured as dummy variable $=1$ if firm has audit committee and 0 otherwise. 


\section{MInstitute"}

\section{Empirical Analysis}

\subsection{Analysis of Whole Sample}

Table II gives the descriptive statistics of sample data for 113 companies that meet the required data for year 2011. The mean value of the ACCR is -.0051 . This average is almost lower than the mean value of accrual conservatism at 0.010 and -.004 that documented by Ahmed and Duellman (2007) and Ahmed, Billings, Morton and Stanford-Hars (2002) respectively.

The mean value of foreign ownership (OWFORE) is $41.5 \%$ with a maximum value of $77 \%$. Such result indicates that approximately half of Jordanian firms' shares are owned by non-Jordanian (foreigners), which may give them the opportunity to control and monitor these firms closely in the future and take part in decision-making (Zureigat, 2011).

As for the independence of board members (BIND), the mean value is $65.26 \%$. This value refers that more than half of Jordanian firms had complied with the requirements of Jordanian code of corporate governance to have an independent directors in their boards to assure the availability of objective decisions. On the other hand, the average board size (BSIZ) is 9.61 members with a standard deviation of 1.466 are compatible with Lipton and Lorsch (1992) who suggested that the members of boards should be ten people, and they preferred size of eight or nine.

Table II also shows that the average of Jordanian firms that have audit committee (AC) was $55 \%$. Our result suggests that there is a lack of commitment in applying the requirements of governance code that require companies to establish an audit committee, where 51 or $45 \%$ of Jordanian companies did not have an audit committee. This result is almost similar to the result of Dea'a (2014) who found that $44 \%$ of Jordanian firms did not have an audit committee. 
Table II: Descriptive Statistics of Variables

\begin{tabular}{llccl} 
Variables & \multicolumn{3}{c}{ Minimum Maximum Mean } & $\begin{array}{l}\text { Std. } \\
\text { Deviation }\end{array}$ \\
\hline ACCRU & -.30 & .30 & -.0051 & .10429 \\
FORE & .08 & .77 & .4147 & .13145 \\
BIND & .27 & 1.00 & .6526 & .16990 \\
BSIZ & 6 & 13 & 9.61 & 1.466 \\
AC & 0 & 1 & .55 & .458
\end{tabular}

Note: See Table I for variables definition

\subsection{Correlation Analysis}

Table III demonstrates the correlations coefficients among dependent and independent variables. The coefficients for foreign ownership, board independence and audit committee are consistent with our expectation that they lead to better governance and employed higher conservatism. On the other hand, the negative coefficient of board size is not consistent with our expectation; this result is supported by the previous studies which concluded that larger size of boards is less effective than smaller size of boards due to difficulties in coordination of task (Agoraki, Delis \&Staikouras, 2010).

The correlation coefficient among foreign ownership and board independence and board size is negative, while a positive coefficient is exists among foreign ownership and audit committee. Board independence has a positive correlation with board size and negative with audit committee. Table III also shows a negative correlation amongboard size and audit committee. 
Table III: Pearson correlation coefficients among variables

\section{ACCRU FORE BIND BSIZ AC}

ACCRU 1

\begin{tabular}{llllll} 
FORE & .175 & 1 & & & \\
BIND & .001 & -.174 & 1 & & \\
BSIZ & $-.201^{*}$ & -.126 & .135 & 1 & \\
AC & $.497^{* *}$ & .058 & $-.315^{* *}$ & -.182 & 1 \\
\hline \hline
\end{tabular}

\subsection{Hypotheses Testing}

Before the regression analyses and hypotheses testing are performed, the assumptions that related to the multiple regression analyses are checked. These assumptions are outliers, normality, linearity, multicollinearity, autocorrelation and homoscedasticity (Coakes\& Steed, 2003; Hair, Black, Babin, Anderson and Latham, 2010). The results concluded that there is no violation of these assumptions.

Table III shows that the model is significant $(\mathrm{F}=12.573)$ ( $\mathrm{Sig} \mathrm{F}=0.00)$. The model explained $29.2 \%$ of the variation in the accrual conservatism (Adjusted $\mathrm{R}^{2}=29.2 \%$ ). This adjusted $\mathrm{R}^{2}$ is higher that the $\mathrm{R}^{2}$ that reported by Shuto and Takada (2010) and Ahmed and Duellman (2007) at $14 \%$ and $12.96 \%$ respectively. The following section provides the results of the relationship among the variables under study as hypothesised previously.

Regarding to the foreign ownership, Table III shows that there is a consistent between our prediction and our actual results. The result illustrates a positive significant relationship among foreign ownership and accrual conservatism $(\mathrm{T}=2.061 ; \mathrm{P}=0.042)$. Our finding is consistent with Mohandi and Odeh (2010) who concluded that firms with higher proportion of foreign ownership contribute positively in improving the quality of financial reports in Jordan. Therefore, hypothesis H1 is supported.

In a similar vein, the results show a positive and significant relationship between board independent and accrual conservatism $(\mathrm{T}=2.509 ; \mathrm{P}=.014)$. This finding is supported by Pfeffer and Salancik (2003) who concluded that independent directors on the boards could protect the resources of corporate and decrease uncertainty level which could promote the flow of information among the corporate and outside parties. Hence, hypothesis $\mathrm{H} 2$ is supported. 
Table III: OLS Regression Results

\begin{tabular}{llllll}
\hline Variable & B & Std. Error & Beta & T & P value \\
\hline FORE & .133 & .064 & .167 & 2.061 & .042 \\
BIND & .131 & .052 & .213 & 2.509 & .014 \\
BSIZ & -.008 & .006 & -.112 & -1.370 & .174 \\
AC & .122 & .019 & .534 & 6.309 & .000 \\
\hline DV & $=$ ACCRU & & & & \\
R $^{2}$ & $=0.318$ & & & & \\
Adj R & $=0.292$ & & & & \\
F Ratio & $=12.573$ & & & & \\
Sig F & $=0.000$ & & & & \\
N & $=113$ & & & & \\
\hline \hline
\end{tabular}

Unexpected relationship between board size and conservatism is revealed through the results of this paper. The results show a negative and not significant relationship between large board size and accrual conservatism $(\mathrm{T}=-1.370 ; \mathrm{P}=.174)$. Lipton and Lorsch (1992) concluded that large size of boards slows decision making as well each member on the board might depend on others to monitor and control management due to the difficulties in coordination of tasks. In U.S, Ahmed and Duellman (2007) reported that the relationship between board size and conservative accounting was not significant. Thus, hypothesis H3 is not supported.

Table III illustrates that there is a positive direction between the presence of an audit committees and accruals conservatism, as well as significant at 5\% ( $\mathrm{T}=6.309 ; \mathrm{P}=.000)$. This finding is supported by agency theory which states that the presence of audit committee improve the financial reporting quality. As well, Abu-Haija (2012) reported that the presence of audit committee limits the manipulation in financial reports among Jordanian firms. Therefore, hypothesis H4 is accepted.

\section{Conclusions}

Positive accounting theory stated that the corporate with good governance structure use more conservative practices (Pourkazemi \& Abdoli, 2011). The outcome of this study seeks to fill the gap on the literature of corporate governance and provide more evidence whether the 
same instrument can be employed in emerging economies like Jordan.

This study also profited from the recommendations of the previous studies to pay more attention on the role of foreign ownership to boost demand on conservatism practices (Faudziah et al., 2014; Smith, Ismail \& Ahmad, 2011). In addition, this study contributes also by employing accrual-based as a proxy for accounting conservatism, since some of previous studies such as Wang (2009) have documented that there are only nine studies in the accounting literature have used accrual-based to measure accounting conservatism.

\section{References}

Abbott, L. J., and S. Parker.(2000). Auditor selection and audit committee characteristics.Auditing: A Journal of Practice \& Theory, 19 (2), 47-66.

Abdullatif, M. (2010). The effectiveness of audit committees in Jordanian public shareholding companies and potential company characteristics affecting it: perceptions from auditors in Jordan. Dirasat: Administrative Sciences, 33(2).

Abu Haija, A. A. (2012). The Application of Fair Value Accounting and Corporate Governance and their Relationship to Financial Statements Manipulation. Unpublished doctoral thesis, University Utara Malaysia

Agoraki, M. E. K., Delis, M. D., \&Staikouras, P. K. (2010).The effect of board size and composition on bank efficiency.International Journal of Banking, Accounting and Finance, 2(4), 357-386.

Ahmed, A. S., \&Duellman, S. (2007). Accounting conservatism and board of director characteristics: An empirical analysis.Journal of Accounting and Economics, 43(2), 411-437.

Ahmed, A. S., Billings, B. K., Morton, R. M., \& Stanford-Harris, M. (2002). The role of accounting conservatism in mitigating bondholder-shareholder conflicts over dividend policy and in reducing debt costs. The Accounting Review, 77(4), 867-890.

Akhtaruddin, M., Hossain, M. A., Hossain, M., \& Yao, L. (2009). Corporate governance and voluntary disclosure in corporate annual reports of Malaysian listed firms. Journal of Applied Management Accounting Research, 7(1), 1-19.

Ali S., Salleh N., \& Hassan S. (2008). Ownership structure and earnings management in Malaysian listed companies: the size effect. Asian Journal of Business and Accounting, 1(2), 89-116.

Ang, J. S., \& Ma, Y. (1999). Transparency in Chinese stocks: A study of earnings forecasts by professional analysts. Pacific-Basin Finance Journal, 7(2), 129-155.

Anonymous.(1996). In Praise of the Family Firm.The Economist 338/7956, 16.

Armstrong, C. S., Core, J. E., \&Guay, W. R. (2014). Do independent directors cause Improvements in Firm Transparency?. Journal of Financial Economics. 
ASE.(2012). Amman Stock Exchange. Retrieved from: http://www.ase.com.jo/en/date

Ball, R. (2001). Infrastructure requirements for an economically efficient system of public financial reporting and disclosure.Brookings-Wharton papers on financial services, 2001, 127-169.

Ball, R., \&Shivakumar, L. (2005). Earnings quality in UK private firms: comparative loss recognition timeliness. Journal of Accounting and Economics, 39(1), 83-128.

Ball, R., \&Shivakumar, L. (2006).The role of accruals in asymmetrically timely gain and loss recognition.Journal of Accounting Research, 44(2), 207-242.

Ball, R., Kothari, S., \& Robin, A. (2000).The effect of international institutional factors on properties of accounting earnings.Journal of Accounting and Economics, 29(1), 1-51.

Ball, R., Robin, A., \& Wu, J. S. (2003). Incentives versus standards: Properties of accounting income in four East Asian countries. Journal of Accounting \& Economics, 36(1-3), 235-270.

Basu, S. (2005). Discussion of "Conditional and Unconditional Conservatism: Concepts and Modeling”. Review of Accounting Studies, 10(2), 311-321.

Bedard, J., Chtourou, S. M., \&Courteau, L. (2004).The effect of audit committee expertise, independence, and activity on aggressive earnings management.Auditing, 23(2), 13-36.

Bhagat, S., \& Black, B. (2000).Board independence and long-term firm performance.Unpublished paper, University of Colorado.

Brown Jr, W. D., He, H., \&Teitel, K. (2006). Conditional conservatism and the value relevance of accounting earnings: An international study. European Accounting Review, 15(4), 605-626.

Chen, K., \& Zhou, J. (2007). Audit committee, board characteristics and auditor switch decisions by Andersen's clients. Contemporary Accounting Research, Vol. 24, No. 4, pp. 1085-1117, 2007.

Coakes,S. J., \& Steed, G. (2003) SPSS withoutAnguish.Sydney:John Wiley \& Sons.

Collier, P., \& Gregory, A. (2000).Audit committee activity and agency costs.Journal of Accounting and Public Policy, 18(4), 311-332.

Congress of the United States of America. 2002. Sarbanes-Oxley Act of 2002. Washington DC, WA US: Congress of the United States of America.

Dalton, C. M., \& Dalton, D. R. (2005). Boards of directors: Utilizing empirical evidence in developing practical prescriptions. British Journal of Management, 16, S91-S97.

Dea'a, O. N. S. (2014). The Relationship between Corporate Governance Mechanisms and Company Attributes on the Accounting Conservatism of Jordanian Listed Companies. Unpublished doctoral thesis, University Utara Malaysia 
DeZoort, F. T., Hermanson, D. R., \&Archambeault, D. S. (2002). Audit Committee Efectiveness: a Synthesis of the Empirical Audit Committee Literature. Journal of accounting literature, 21, 38-75.

Ellstrand, A. E., C. M. Daily, J. L. Johnson, and D. R. Dalton. 1999. Governance by committee: The influence of board of directors' committee composition on corporate performance. Journal of Business Strategies 16 (1): 67-88.

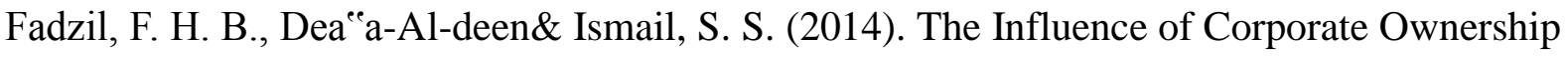
Structure and Board Memberse Skills on the Accounting Conservatism: Evidence from Non-Financial Listed Firms in Amman Stock Exchange. International Journal of Accounting and Financial Reporting, 4(1).

Fama, E. F., \& Jensen, M. C. (1983).Separation of ownership and control.Journal of Law \& Economics, 26(2), 301-326.

Fan, J. P. H., \& Wong, T. J. (2002).Corporate ownership structure and the informativeness of accounting earnings in East Asia.Journal of Accounting and Economics, 33(3), 401-425.

Gay, G. and Simnett, R. (2007), Auditing and Assurance Services in Australia, McGraw-Hill Irwin,

Givoly, D., \&Hayn, C. (2000). The changing time-series properties of earnings, cash flows and accruals: Has financial reporting become more conservative?.Journal of Accounting and Economics, 29(3), 287-320.

Givoly, D., \&Hayn, C. (2002). Rising conservatism: implications for financial analysis. Financial Analysts Journal, 56-74.

Goodwin, J., \&Seow, J. L. (2002). The influence of corporate governance mechanisms on the quality of financial reporting and auditing: Perceptions of auditors and directors in Singapore. Accounting \& Finance, 42(3), 195-223.

Gulzar, M., \& Wang, Z. (2011). Corporate governance characteristics and earnings management: empirical evidence from Chinese listed firms. International Journal of Accounting and Financial Reporting, 1(1), 133-151.

Hair, J. F., Black, W. C., Babin, B. J., Anderson, R. E., \& Latham, R. (2010). Multivariate data analysis (7th ed). New Jersey: Pearson3

Hamdan A, M., Abzakh.(2011). Factors Influencing the Level of Accounting Conservatism in the Financial Statements.International Business Research, 4 (3), 145-156.

Hamdan, A. M. (2012a). The Impact of Auditing Quality on the Enhancement of the Level of Accounting Conservatism: an empirical study from Amman Stock Exchange. Institute of Public Administration in Riyadh, 1, 1-31.

Hart, O. (1995). Corporate governance: some theory and implications. The economic journal, 678-689. 
Hayes, R., Mehran, H., \& Schaefer, S. (2004). Board committee structures, ownership and firm performance. In A Revised Version of the Paper Presented at the Federal Reserve Bank of New York Finance Seminar Series, at New York University.

Hermalin, B. E., \&Weisbach, M. S. (2003). Boards of directors as an endogenously determined institution: a survey of the economic literature. Economic Policy Review, 9 (1) 7-26.

Jensen, M. C. (1993). The modern industrial revolution, exit, and the failure of internal control systems.The Journal of Finance, 48(3), 831-880.

Jensen, M. C., and W. H. Meckling. (1976). Theory of the firm: Managerial behavior, agency costs and ownership structure. . Journal of Financial Economics 3 (4), 305-360.

http://www.sdc.com.jo/arabic/images/stories/pdf/corporate_governance_companies.p

JSC, Jordanian Securities Commission. (2009). Corporate governance code for shareholding companies listed on Amman Stock Exchange. 1-16. Retrieved from: http://www.sdc.com.jo/arabic/images/stories/pdf/corporate_governance_companies.pdf

Klai, N., \&Omri, A. (2011). Corporate governance and financial reporting quality: The case of Tunisian firms. International Business Research, 4(1), 158-166.

Klein, A. (1998). Firm Performance and Board Committee Structure 1. The Journal of Law and Economics, 41(1), 275-304.

Klein, A. (2002). Audit committee, board of director characteristics, and earnings management.Journal of Accounting and Economics, 33(3), 375-400.

Kung, F.-H., K. James, and C. Cheng. (2008). Is accounting conservatism more pronounced for Chinese companies cross-listed on an overseas exchange? Paper presented at the In Accounting and Finance Association of Australia and New Zealand (AFAANZ) Conference, Sydney.

Kwon, Y. K., Newman, D. P., \&Suh, Y. S. (2001). The demand for accounting conservatism for management control. Review of Accounting Studies, 6(1), 29-52.

Kwon, Y. K. (2005). Accounting conservatism and managerial incentives.Management science, 51(11), 1626-1632.

Kwon, Y. K., Newman, D. P., \&Suh, Y. S. (2001).The demand for accounting conservatism for management control.Review of Accounting Studies, 6(1), 29-52.

LaFond, R., \& Watts, R. L. (2008).The information role of conservatism.Accounting Review, 83(2) 447-478.

Lanfranconi, C. P., \& Robertson, D. A. (2002). Corporate financial reporting: The role of the board of directors. Ivey Business Journal, 67(1), 1-3.

Lara, J. M. G., Osma, B. G., \&Penalva, F. (2007). Board of directors' characteristics and 
conditional accounting conservatism: Spanish evidence. European Accounting Review, 16(4), 727-755.

Lasfer, M. A. (2004). On the monitoring role of the board of directors: The case of the adoption of Cadbury recommendations in the UK. Advances in Financial Economics 9, 287-326.

Lehn, K. M., Patro, S., \& Zhao, M. (2009). Determinants of the Size and Composition of US Corporate Boards: 1935-2000. Financial Management, 38(4), 747-780.

Linck, J. S., Netter, J. M., \& Yang, T. (2008).The determinants of board structure. Journal of Financial Economics, 87(2), 308-328.

Lipton, M., \&Lorsch, J. W. (1992). Modest Proposal for Improved Corporate Governance, A. Bus. Law., 48, 59.

Lobo, G. J., \& Zhou, J. (2006). Did conservatism in financial reporting increase after the Sarbanes-Oxley Act? Initial evidence.Accounting horizons, 20(1), 57-73.

Mohandi, A., \&Odeh, A. (2010). The effect of ownership structure on the quality of financial statements in Jordan. Journal of Business Administration, 19(2), $1-233$

Nimer, K. M., Warrad, L., \&Khuraisat, O. (2012). The Effect of Audit Committee's Effectiveness on Dividend Payout Policy: Evidence from the Jordanian Firms. International Journal of Business and Management, 7(7), p172.

Pfeffer, J. (1972). Size and composition of corporate boards of directors: The organization and its environment. Administrative Science Quarterly, 218-228.

Pfeffer, J., \&Salancik, G. R. (2003).The external control of organizations: A resource dependence perspective: Stanford Business Books.

Pfeffer, J., \&Salancik, G. R. (2003). The external control of organizations: A resource dependence perspective: Stanford Business Books.

Pourkazemi, A., \&Abdoli, M. (2011).Corporate Governance and Conservatism. Paper presented at the European Conference on Management, Leadership \& Governance.

Rodriguez, M. (2010). Big auditors, private firms and accounting conservatism: Spanish evidence. European Accounting Review, 19(1), 131-159.

Shuto, A., \& Takada, T. (2010). Managerial Ownership and Accounting Conservatism in Japan: A Test of Management Entrenchment Effect. Journal of Business Finance \& Accounting, 37(7 - 8), 815-840.

Sterling, R. R. (1970). Theory of the measurement of enterprise income. Kansas: Lawrence: University Press of Kansas.

Vera-Munoz, S. C. (2005). Corporate governance reforms: redefined expectations of audit committee responsibilities and effectiveness. Journal of Business Ethics, 62(2), 115-127. 


\section{Macrothink}

International Journal of Learning \& Development ISSN 2164-4063 2014, Vol. 4, No. 4

Wang, R. (2009). Accounting Conservatism: A Thesis Submitted to the Victoria University of Wellington in Fulfilment of the Requirements for the Degree of Doctor of Philosophy in Accounting.

Watts, R. (2003a). Conservatism in accounting-part II: evidence and research opportunities. Simon Business School Working Paper No. FR 03-25.

Watts, R. L. (2003b). Conservatism in accounting part I: Explanations and implications. Accounting horizons, 17(3), 207-221.

Watts, R. L. (2006). What has the invisible hand achieved?. Accounting and Business Research, 36(sup1), 51-61.

Yunos, R. M., Smith, M., Ismail, Z., \& Ahmad, S. A. (2011). Inside Concentrated Owners, Board of Directors and Accounting Conservatism. Annual Summit on Business and Entrepreneurial Studies. Proceeding.

Yunos, R. M., Smith, M., \& Ismail, Z. (2010). Accounting Conservatism and Ownership Concentration: Evidence from Malaysia. Journal of Business and Policy Research, 5(2) 1 15.

Zureigat, Q. M. (2011). The Effect of Ownership Structure on Audit Quality: Evidence from Jordan. International Journal of Business and Social Science V, 2 (10), 38-47. 